Volume 2 Issue 1, March 2017: pp. 416-428. Copyright (c) 2018 HOLREV. Faculty of Law, Halu Oleo University, Kendari, Southeast Sulawesi, Indonesia. ISSN: 2548-1762 | e-ISSN: 2548-1754. Open Access at: http://ojs.uho.ac.id/index.php/holrev/

\title{
Perlindungan Hukum Pencipta yang Dirugikan Haknya atas Tindakan Plagiarisme
}

\author{
Legal Protection for the Impaired Creator by Plagiarism Act
}

\author{
Guswan Hakim \\ Dosen Fakultas Hukum Halu Oleo \\ E-mail: guswan_hakim@yahoo.com
}

\begin{abstract}
The purpose of this study is to know about whether the applicable legislation in Indonesia has provided a clear and uniform definition related to the concept of plagiarism in the work of art, literature and scientific papers and Is the applicable legislation in Indonesia at the time, has provided adequate legal protection for the aggrieved creators in the act of plagiarism in works of art, literature and scientific work. This writing uses normative writing method, the approach used in this writing is the approach of the law (Statute Approach). As for the results of the study is the Criminal Code does not recognize the term plagiarism otherwise UUHC does not mention explicitly but plagiarism implied in chapters 41,42,43 and 44 UUHC No. 28 Year 2014 which is called by exceptions and restrictions on copyright, while copyright violations are formulated separately in different articles. UU Sisdiknas calls plagiarism without any further explanation, but states that the act of plagiarism can be used as a basis for uprooting one's academic degree. While Permendiknas Number 17 of 2010 on prevention and prevention of plagiarism in universities has provided clarity on the concept of plagiarism action and prohibited actions. and legal protection on UUHC, UU Sisdiknas and Permendiknas No. 17 Year 2010 is based on 5 parameters, namely the recognition of rights to the creator, the determination of plagiarism as a crime, the formulation of criminal sanctions, the existence of additional criminal sanctions, and dispute resolution mechanism. These parameters have provided legal protection for the most adequate creators. to the perpetrators of plagiarism can be accountable Answer Criminal, Administration and Civil and can be applied to the Institution.
\end{abstract}

Keyword: legal protection, plagiarism, responsibility.

Abstrak: Tujuan penelitian ini adalah untuk mengetahui tentang apakah peraturan perundang-undangan yang berlaku di Indonesia telah memberikan definisi yang jelas dan seragam berkaitan dengan konsep tindakan plagiarisme dalam karya seni, sastra dan karya ilmiah dan Apakah peraturan perundang-undangan yang berlaku di Indonesia pada saat ini, telah memberikan perlindungan hukum yang memadai bagi pencipta yang dirugikan dalam tindakan plagiarisme dalam karya seni, sastra 
dan karya ilmiah. Penulisan ini menggunakan metode penulisan normatif, pendekatan yang digunakan dalam penulisan ini adalah pendekatan undangundang (Statute Approach). adapun hasil penelitian adalah KUHP tidak mengenal istilah plagiarisme sebaliknya UUHC tidak menyebut secara eksplisit akan tetapi plagiarisme tersirat dalam Pasal 41, 42, 43 dan 44 UUHC No. 28 Tahun 2014 yang disebut dengan pengecualian dan pembatasan hak cipta, sedangkan pelanggaran hak cipta dirumuskan tersendiri dalam pasal yang berbeda. UU Sisdiknas menyebut plagiarisme tanpa ada penjelasan lebih lanjut, akan tetapi menyatakan bahwa tindakan plagiarisme dapat dijadikan dasar untuk mencabut gelar akademik seseorang. Sedangkan Permendiknas Nomor 17 Tahun 2010 tentang pencegahan dan penanggulangan plagiat di perguruan tinggi telah memberikan kejelasan konsep tindakan plagiarisme beserta tindakan yang dilarang. dan perlindungan hukum pada UUHC, UU Sisdiknas dan Permendiknas No. 17 Tahun 2010 didasarkan pada 5 parameter yaitu pengakuan hak bagi pencipta, penetapan plagiarisme sebagai tindak pidana, perumusan sanksi pidana, adanya pidana tambahan, dan mekanisme penyelesaian sengketa. Parameter tersebut telah memberikan perlindungan hukum bagi pencipta yang paling memadai. kepada pelaku plagiarisme dapat dipertanggung Jawab secara Pidana, Administrasi maupun Perdata serta dapat diterapkan kepada Institusi.

Kata kunci: perlindungan hukum, plagiarisme dan tanggung jawab.

\section{PENDAHULUAN}

Plagiarisme di Indonesia tidak hanya terjadi dibidang akademik akan tetapi terjadi juga dibidang seni dan budaya. Dalam bidang akademik, selain kasus plagiarism yang terjadi di Institut Teknologi Bandung yang berakibat dibatalkannya gelar Doktor untuk Muhammad Zuliansyah, dalam karya ilmiah berjudul "On 3D Topological Relationship", MZ diduga menjiplak karya ilmuwan Siyka Zlatanova. Makalah itu dibawa MZ ke konferensi ilmiah di Chengdu, Cina pada September 2008. ${ }^{1}$

Di bidang seni dan budaya, ternyata banyak kasus-kasus plagiarism yang juga menjadi perhatian publik misalnya: dibidang seni sastra, puisi karya Taufiq Ismail yang berjudul kerendahan hati' juga merupakan puisi jiplakan (plagiat) dari karya seorang penyair klasik asal Amerika Serikat, Douglas Malloch, yang berjudul "Be the Best of Whatever You Are"2. Puisi tersebut mengundang silang pendapat dari para sastrawan maupun orang awam, ada yang membela Taufiq Ismail dengan alasan "terinspirasi" tapi ada juga yang dengan keras mengatakan bahwa puisi tersebut adalah plagiarisme, silang

1 “Gelar Magister Zuliansyah Tak Dicabut", Detikcom, https://news.detik.com/berita/d-1344458/gelarmagister-zuliansyah-tak-dicabut, 23 April 2010. diakses pada tanggal 11 Januari 2018.

2 Wahyu Chandra, "Motif Dibalik Tuduhan Plagiarisme Penyair Taufik Ismail", Kompasiana, https://www.kompasiana.com/wahyuch/motif-di-balik-tuduhan-plagiarisme-penyair-taufikismail 5500a6baa333119f6f511b49, 3 April 2011, diakses pada tanggal 11 Januari 2018. 
pendapat ini berlangsung sangat seru di jejaring sosial baik Facebook maupun Twitter selama berhari-hari.

Puisi karya Chairil Anwar yang berjudul "Karawang Bekasi” yang diduga juga ada indikasi plagiarisme dari karya penyair Amerika Serikat Archibald MacLeish yang berjudul “The Young Dead Soldiers Do Not Speak" tetap menimbulkan polemik sepanjang masa, karena sebagian penyair mengatakan itu adalah plagiarisme sedangkan yang lain termasuk HB Yassin menyatakan bahwa karya Chairil Anwar tersebut merupakan karya saduran dan bukan plagiarisme.

Selanjutnya di bidang seni musik kasus plagiarisme yang sempat menjadi perhatian publik adalah kasus plagiarisme lagu tema (theme song) dalam film "Ekskul” yang menjadi pemenang FFI 2006, yang ternyata menjiplak lagu tema "The Gladiator". Kasus ini menuai protes besar dari Universal Music Indonesia dan mengirimkan somasi ke produser film tersebut, akhirnya dewan juri FFI membatalkan kemenangan film tersebut.

Berbagai fenomena yang berkaitan dengan tindakan plagiarisme menjadi penting untuk dikaji karena faktanya tindakan tersebut terus menerus terjadi hal ini didukung oleh perkembangan teknologi informasi dan konvergensi teknologi yang sangat cepat serta mudah diakses di Indonesia. ${ }^{3}$

Berbagai situs-situs pelayanan penjualan informasi secara online, yang dengan sangat gamblang memperjual belikan hasil karya ilmiah baik berupa skripsi, tesis dan berbagai disiplin ilmu. Situs-situs tersebut pada umumnya menampilkan tagline "jurnal skripsi tesis-layanan pencarian data 24 jam", akan tetapi pada kenyataannya tidak ada yang gratis dari informasi yang disediakan, bahkan beberapa situs tersebut terang-terang memasang harga, misalnya 300 ribu rupiah untuk skripsi, 500 ribu rupiah untuk tesis. Situs ini juga melayani pengiriman data baik secara online dalam format Word ataupun PDF melalui email ataupun dalam bentuk softcopy dalam CD ke seluruh wilayah Indonesia. ${ }^{4}$

3 "Marak, Plagiarisme Internet di Sekolah", Detikcom, http://inet.detik.com/cyberlife/d-1382658/marakplagiarisme-internet-di-sekolah-, 21 Jun 2010, diakses pada tanggal 9 Januari 2018. lihat juga artikel, "Kisah Isu Plagiarisme Sekum PP Muhammadiyah", https://news.detik.com/berita/d-1428112/kisah-isuplagiarisme-sekum-pp-muhammadiyah, 26 Agustus 2010, diakses pada tanggal 11 Januari 2018.

4 Pada halaman harga dan layanan, pemilik situs ini menampilkannya sebagai berikut: layanan kami 24 jam. Skripsi Rp 300 ribu Tesis Rp 500 ribu dan mungkin akan segera dinaikkan. Silakan SMS judul dan alamat email Anda, kirim ke nomor HP 081904051059 atau Telp: (0274) 7400200 kami melayani pemesanan dari seluruh kota di Indonesia.; dari Aceh sampai Papua (termasuk Dili-Timor Leste dan Malaysia).pengiriman berupa file via email sehingga langsung sampai pada hari ini juga, atau bisa melalui Pos/Tiki (2-7 hari). Layanan ini bersifat referensi atau bahan pembelajaran, kami tidak mendukung plagiarisme. Kami melayani juga makalah dan terjemahan (Rp 20. 000/lembar). Mohon maaf, kami hanya 
Situs seperti itu juga menampilkan disclaimer bahwa data yang disediakan hanya untuk referensi dan tidak mendukung plagiarisme, akan tetapi siapa yang dapat memberikan jaminan bahwa data tersebut tidak disalah gunakan dan apakah tindakan semacam itu dapat dikenakan ketentuan sanksi pidana dalam berbagai peraturan perundangan di Indonesia ataukah tidak, hal ini yang membuat penelitian ini penting dan menarik untuk dilakukan.

Dalam penelitian ini masalah yang dikaji sebagai berikut: Apakah peraturan perundang-undangan yang berlaku di Indonesia pada saat ini, telah memberikan perlindungan hukum yang memadai bagi pencipta yang dirugikan dalam tindakan plagiarisme dalam karya seni, sastra dan karya ilmiah?

\section{METODE PENELITIAN}

Penulisan ini menggunakan metode penulisan normatif, dilakukan dengan cara mengumpulkan dan mempelajari data yang terdapat dalam buku dan literatur, tulisantulisan ilmiah, dokumen-dokumen atau tulisan para ahli, yurisprudensi serta berbagai macam peraturan perundang-undangan. Metode pendekatan yang dilakukan yaitu pendekatan undang-undang (statute approach). Pendekatan undang-undang (statute approach) dilakukan dengan menelaah semua undang-undang dan regulasi yang bersangkut paut dengan isu hukum yang sedang ditulis.

\section{ANALISIS DAN PEMBAHASAN}

\section{Konsep Plagiarisme dalam Berbagai UU di Indonesia}

Perlindungan hukum pada dasarnya adalah adanya pengakuan hak, perumusan pelanggaran hak yang bisa termasuk dalam ranah hukum perdata, pidana maupun administrasi serta mekanisme penyelesaian sengketa, serta perumusan sanksi pidana atau administratif.

Dalam KUHP yang merupakan induk dari hukum pidana materiil, maka perlindungan pencipta dapat ditinjau dari Aspek larangan berbuat yang disertai ancaman pidana dalam artian ini sering disebut dengan tindak pidana atau perbuatan pidana (berasal dari katastrafbaarfeit), yang juga sering disebut delik (berasal dari kata delict). Tindak pidana merupakan rumusan tentang perbuatan yang dilarang untuk dilakukan

merespons yang serius saja. (Jurnal Skripsi Thesis, www.Jurnalskripsithesis.com, diakses pada tanggal 10 Januari 2018). 
(dalam peraturan perundang-undangan) yang disertai ancaman pidana bagi siapa yang melanggar larangan tersebut. Jadi, perbuatan (feit) di sini adalah unsur pokok dari suatu tindak pidana yang dirumuskan tersebut. ${ }^{5}$

Namun dalam hal pertanggungjawaban tindak pidana untuk bisa meminta pertanggungjawaban seseorang, maka harus cukup bukti yang bisa membuktikan unsur kesalahan pelaku atas suatu tindakan yang orang tersebut lakukan. Jadi masalah pembuktian memegang perkara penting dalam penegakan hukum pidana.

Perlindungan pencipta dan ciptaan secara tersirat dapat disimpulkan dari ketentuan Pasal 380 (1) ke-1 KUHP.

Pasal 380 KUHP sebagai berikut: 6

1. Diancam dengan pidana penjara paling lama dua tahun delapan bulan atau denda paling banyak lima ribu rupiah:

Ke-1 barang siapa menaruh suatu nama atau secara palsu di atas atau di dalam suatu kesusastraan, keilmuan, kesenian dan kerajinan atau memalsu nama atau tiada yang asli, dengan maksud supaya karenanya orang mengira bahwa itu benar-benar buah hasil orang yang nama atau tandanya olehnya ditaruh di atas atau di dalamnya tadi;

Ke-2 barang siapa dengan menjual, menawarkan, menyerahkan, mempunyai persediaan ke Indonesia, buah hasil kesusastraan, kesenian keilmuan dan kerajinan yang di dalamnya atau di atasnya telah ditaruh nama atau tanda yang palsu, atau yang nama dan nama atau tandanya telah ditaruh secara palsu tadi.

2. Jika buah hasil itu kepunyaan terpidana, boleh dirampas.

Ketentuan tersebut, dapat dikategorikan dalam tindak pidana yang dilakukan dalam hal jual beli walaupun perbuatan materiilnya adalah memalsukan. Hal ini lebih ditekankan pada larangan melakukan jual beli barang misalnya lukisan, karya ilmiah dan kerajinan yang dipalsukan. Tujuan dari ketentuan pasal ini bukan melindungi hak cipta, tetapi melarang kebohongan-kebohongan yang keterlaluan dibidang karya ilmiah, seni dan kerajinan dengan cara membubuhkan nama atau tanda palsu.

$5 \quad$ Nikmah Fitriah, "Tinjauan Yuridis tentang Kriteria Pencemaran dan Perusakan Lingkungan Menurut UU No. 32 Tahun 2009 Tentang Pengelolaan Lingkungan Hidup", Halu Oleo Law Review (HOLREV), Vol. 1, Issue 2, September 2017, http://ojs.uho.ac.id/index.php/holrev/article/view/3643/3137, diakses pada tanggal 17 Februari 2018, hlm. 22.

6 KUHP dan KUHAP, Jakarta: Permata Pers, 2008, hlm. 126. 
Selain itu, perbuatan pidana dalam Pasal 380 (1) ke-1 KUHP yang dibohongi adalah setiap orang yang melihat hasil pekerjaan tersebut tanpa disebutkan akibat dari kebohongan itu, baik pelaku maupun orang yang melihat. Jadi tindak pidana ini juga sudah terjadi, misalnya si pemalsu merasa bangga mempunyai hasil pekerjaan dari orang namanya dipalsukan itu tanpa perlu merugikan siapa pun. Selanjutnya dari ketentuan Pasal 380 (1) ke-2 KUHP menjelaskan bahwa orang dapat tertipu dengan membeli barang seni yang dipalsukan atau yang ditawari hasil pekerjaan tersebut.

Dalam UUHC pengakuan atas hak-hak cipta terbagi dalam dua jenis yaitu hak ekonomi dan hak moral. Hak ekonomi ini meliputi hak penggandaan (reproduction right); hak penyebarluasan (distribution right); hak adaptasi (adaptation right) yang meliputi hak penerjemahan, hak administrasi, hak film; hak pertunjukan (performance right); hak atas rekaman suara (mechanical right); hak atas program siaran (broadcasting right). ${ }^{7}$ Perwujudan perlindungan hukum atas hak ekonomi ini menjelma dalam penentuan jenis perbuatan yang dilarang beserta sanksi pidananya diatur dalam Pasal 112 UUHC.

Sedangkan hak moral adalah hak yang melekat pada pencipta, yaitu hak untuk selalu dicantumkan nama pencipta dalam setiap ciptaannya dan hak atas keutuhan ciptaannya terhadap perubahan isi maupun judul. Hak moral ini diatur dalam Pasal 5 UUHC sebagai berikut:

(1) Hak moral sebagaimana dimaksud dalam Pasal 4 merupakan hak yang melekat secara abadi pada diri Pencipta untuk:

a. tetap mencantumkan atau tidak mencantumkan namanya pada salinan sehubungan dengan pemakaian Ciptaannya untuk umum;

b. menggunakan nama aliasnya atau samarannya;

c. mengubah Ciptaannya sesuai dengan kepatutan dalam masyarakat;

d. mengubah judul dan anak judul Ciptaan; dan

e. mempertahankan haknya dalam hal terjadi distorsi Ciptaan, mutilasi Ciptaan, modifikasi Ciptaan, atau hal yang bersifat merugikan kehormatan diri atau reputasinya.

(2) Hak moral sebagaimana dimaksud pada ayat (1) tidak dapat dialihkan selama Pencipta masih hidup, tetapi pelaksanaan hak tersebut dapat dialihkan dengan

M. Djumhana dan R. Djubaidillah, Hak Milik Intelektual (Sejarah, Teori dan Prakteknya di Indonesia), Bandung: Citra Aditya Bakti, 1997. hlm. 51-54 
wasiat atau sebab lain sesuai dengan ketentuan peraturan perundangundangan setelah Pencipta meninggal dunia.

(3) Dalam hal terjadi pengalihan pelaksanaan hak moral sebagaimana dimaksud pada ayat (2), penerima dapat melepaskan atau menolak pelaksanaan haknya dengan syarat pelepasan atau penolakan pelaksanaan hak tersebut dinyatakan secara tertulis.

Hak moral ini tidak bisa dialihkan kepemilikannya seperti hak ekonomi. Hak moral ini merupakan hak yang akan mengikuti karya cipta ke mana pun karya cipta itu beralih, hak ini biasa disebut dengan droit de suite karena tetap melekat pada ciptaan walaupun kepemilikan ciptaan tersebut sudah berpindah tangan.

Berkaitan dengan upaya penyelesaian sengketa, UUHC memberikan cara atau mekanisme bagi pencipta dan atau pemegang hak cipta untuk mempertahankan haknya dengan cara atau mekanisme ADR, arbitrase atau pengadilan Niaga. ${ }^{8}$ Dan atau perkara pidana. $^{9}$

a. Perkara perdata, Pasal 99 UUHC menyatakan:

(1) Pencipta, Pemegang Hak Cipta, atau pemilik Hak Terkait berhak mengajukan gugatan ganti rugi kepada Pengadilan Niaga atas pelanggaran Hak Cipta atau produk Hak Terkait.

(2) Gugatan ganti rugi sebagaimana dimaksud pada ayat (1) dapat berupa permintaan untuk menyerahkan seluruh atau sebagian penghasilan yang diperoleh dari penyelenggaraan ceramah, pertemuan ilmiah, pertunjukan atau pameran karya yang merupakan hasil pelanggaran Hak Cipta atau produk Hak Terkait.

Selain itu pemegang hak cipta atau ahli warisnya juga berhak meminta putusan provisi atau putusan sela kepada Pengadilan Niaga agar memerintahkan pelanggar menghentikan segala kegiatan pelanggaran hak cipta agar tidak timbul kerugian yang lebih besar bagi pemegang hak cipta. ${ }^{10}$ Gugatan perdata ini dapat di ajukan di Pengadilan Niaga ${ }^{11}$ yang berkedudukan di 4 kota besar di Indonesia yaitu Medan, Jakarta, Surabaya dan Makassar.

8 Pasal 95 UUHC.

9 Pasal 110 dan 112 UUHC.

10 Pasal 99 ayat (3) UUHC.

11 Pasal 100 UUHC. 
Sedangkan pelanggaran atas hak moral dari pencipta tetap dapat diajukan oleh pencipta atau ahli warisnya bila pencipta telah meninggal dunia.

b. Melalui jalur hukum pidana. Pasal 95 ayat (4) UUHC No. 28 Tahun 2014 menetapkan bahwa Selain pelanggaran Hak Cipta dan/atau Hak Terkait dalam bentuk Pembajakan, sepanjang para pihak yang bersengketa diketahui keberadaannya dan/atau berada di wilayah Negara Kesatuan Republik Indonesia harus menempuh terlebih dahulu penyelesaian sengketa melalui mediasi sebelum melakukan tuntutan pidana.

c. Melalui Alternatif Penyelesaian Sengketa. Pasal 95 UUHC ayat (1) menyatakan bahwa Penyelesaian sengketa Hak Cipta dapat dilakukan melalui alternatif penyelesaian sengketa, arbitrase, atau pengadilan. Berdasarkan pasal tersebut di atas, selain penyelesaian sengketa melalui jalur perdata dan pidana, para pihak juga dapat menggunakan arbitrase dan alternatif penyelesaian sengketa lainnya bahkan sebelum dilakukan tuntutan pidana mediasi wajib dilakukan oleh para pihak terlebih dahulu.

Dari analisis UUHC menunjukkan bahwa UUHC telah memberikan perlindungan hukum yang memadai bagi pencipta, hal ini dapat dibuktikan dengan adanya pengakuan hak serta perumusan tindak pidana baik yang berkaitan dengan plagiarisme maupun yang berkaitan dengan pelanggaran hak cipta beserta sanksi pidananya. UUHC juga memberikan berbagai alternatif upaya penyelesaian sengketa bagi pencipta yang dirugikan haknya, tanpa mengurangi hak pemerintah untuk menegakkan hukum hak cipta secara efektif.

Dalam Pasal 25 ayat (2)) Undang-undang Nomor 20 Tahun 2003 tentang Sistem Pendidikan Nasional menyebutkan secara langsung bahwa Lulusan perguruan tinggi yang karya ilmiahnya digunakan untuk memperoleh gelar akademik, profesi atau vokasi terbukti merupakan jiplakan dicabut gelarnya. Jadi, disebutkan secara langsung tindakan yang dilakukan (menjiplak) dan pelakunya (lulusan perguruan tinggi) yang merupakan plagiator,. Selain sanksi administratif, ada juga sanksi pidana yang diatur dalam Pasal 70 UU Sisdiknas sebagai berikut: "lulusan yang karya ilmiah yang digunakannya untuk mendapatkan gelar akademik, profesi, atau vokasi sebagaimana dimaksud dalam Pasal 25 ayat (2) terbukti merupakan jiplakan dipidana dengan pidana penjara paling lama dua tahun dan/atau pidana denda paling banyak Rp 200, 000,000, 00 (dua ratus juta rupiah)." 
Selain mengatur tentang tindakan plagiarisme. UU Sisdiknas juga melarang dan menyatakan sebagai tindak pidana atas penerbitan ijazah palsu dan penggunaannya sebagaimana tercantum dalam Pasal 67, 68 dan 69 UU Sisdiknas sebagai berikut:

Pasal 67:

1. Perseorangan, organisasi, atau penyelenggara pendidikan yang memberikan ijazah, sertifikat kompetensi, gelar akademik, profesi, dan/atau vokasi tanpa hak dipidana dengan pidana penjara paling lama sepuluh tahun dan/atau pidana denda paling banyak Rp 1.000, 000, 000, 00 (satu miliar rupiah)

2. Penyelenggara perguruan tinggi yang dinyatakan ditutup berdasarkan Pasal 21 ayat (5) dan masih beroperasi dipidana dengan pidana penjara paling lama sepuluh tahun dan/atau pidana denda paling banyak Rp 1. 000, 000, 000, 00 (satu miliar rupiah).

3. Penyelenggara pendidikan yang memberikan sebutan guru besar atau profesor dengan melanggar Pasal 23 ayat (1) dipidana dengan paling banyak Rp 1. 000, 000, 000, 00 (satu miliar rupiah).

4. Penyelenggara pendidikan jarak jauh yang tidak memenuhi persyaratan sebagaimana dimaksud dalam Pasal 31 ayat (3) dipidana dengan pidana penjara paling lama sepuluh tahun dan/atau pidana denda paling banyak Rp 1 . 000, 000, 000, 00 (satu miliar rupiah).

Pasal 68:

1. Setiap orang yang membantu memberikan ijazah, sertifikat, kompetensi, gelar akademik, profesi, dan/atau vokasi dari satuan pendidikan yang tidak memenuhi persyaratan pidana dengan pidana penjara paling lam lima tahun dan/atau pidana denda paling banyak Rp 500. 000, 000, 00 (lima ratus miliar rupiah).

2. Setiap orang yang menggunakan ijazah, sertifikat kompetensi, gelar akademik, profesi, dan/atau vokasi yang diperoleh dari satuan pendidikan yang tidak memenuhi persyaratan dipidana dengan pidana penjara paling lama lima tahun dan/atau pidana denda paling banyak Rp 500. 000, 000, 00 (lima ratus juta rupiah).

3. Setiap orang yang menggunakan gelar lulusan yang tidak sesuai dengan bentuk dan singkatan yang diterima dari perguruan tinggi yang bersangkutan sebagaimana dimaksud dalam Pasal 21 ayat (4) dipidana dengan pidana penjara paling lama dua tahun dan/atau pidana denda paling banyak Rp 200. 000, 000, 00 (dua ratus juta rupiah).

4. Setiap orang yang memperoleh dan/atau menggunakan sebutan guru besar yang tidak sesuai dengan Pasal 23 ayat (1) dan/atau ayat (2) dipidana dengan pidana penjara paling lama lima tahun dan/atau pidana denda paling banyak Rp 500, 000, 000, 00 (lima ratus juta rupiah).

\section{Pasal 69}

1. Setiap orang yang menggunakan ijazah, sertifikat kompetensi, gelar akademik, profesi, dan/atau vokasi yang terbukti palsu dipidana dengan pidana penjara paling lama lima tahun dan/atau pidana denda paling banyak Rp 500, 000, 000, 00 (lima ratus juta rupiah). 
2. Setiap orang yang dengan sengaja tanpa hak menggunakan ijazah dan/atau sertifikat kompetensi sebagaimana dimaksud dalam Pasal 61 ayat (2) dan ayat (3) yang terbukti palsu dipidana dengan pidana paling lama lima tahun dan/atau pidana denda paling banyak Rp 500. 000, 000, 00 (lima ratus juta rupiah).

Dari ketentuan UU Sisdiknas ini maka persoalan plagiarisme tidak lagi berada pada ranah etika ataupun integritas moral akan tetapi sudah masuk dalam ranah hukum administrasi dan hukum pidana, dengan demikian dapat disampaikan bahwa UU Sisdiknas juga menyediakan perlindungan hukum yang memadai bagi korban tindakan plagiarisme. Selain UU Sisdiknas dalam Permendiknas No. 17 Tahun 2010 tentang pencegahan dan penanggulangan plagiat di perguruan tinggi telah menguraikan dengan jelas dan rinci tentang tindakan plagiarisme, serta juga menguraikan dengan jelas sanksi administratif yang dapat dijatuhkan kepada pelaku (mahasiswa dan atau dosen) berkaitan dengan tindakan plagiarisme. Berikut ini adalah bentuk sanksi plagiat yang dilakukan oleh mahasiswa dan dosen:

a. Sanksi bagi mahasiswa yang melakukan plagiarisme dalam Pasal 12 ayat (1) Permendiknas Nomor 17 Tahun 2010 tentang Pencegahan dan Penanggulangan Plagiat di Perguruan Tinggi yang berbunyi: Sanksi bagi mahasiswa yang terbukti melakukan plagiat sebagaimana dimaksudkan dalam Pasal 10 ayat (4), secara berurutan dari yang paling ringan sampai dengan yang paling berat, terdiri atas:

1. Teguran

2. Peringatan tertulis

3. Penundaan pemberian sebagian hak mahasiswa

4. Pembatalan nilai satu atau beberapa mata kuliah yang diperoleh mahasiswa

5. Pemberhentian dengan hormat dari status sebagai mahasiswa

6. Pemberhentian tidak dengan hormat dari status sebagai mahasiswa, atau

7. Pembatalan ijazah apabila mahasiswa telah lulus dari suatu program

b. Sanksi bagi dosen yang melakukan plagiarisme diatur dalam Pasal 12 ayat (2) Permendiknas Nomor 17 Tahun 2010 tentang pencegahan dan penanggulangan plagiat di perguruan tinggi yang berbunyi: sanksi bagi dosen/tenaga kependidikan yang terbukti melakukan plagiat sebagaimana 
dimaksudkan dalam Pasal 11 ayat (6) secara berurutan dari yang paling ringan sampai dengan yang paling berat, terdiri atas:

1. Teguran

2. Peringatan tertulis

3. Penundaan pemberian hak dosen/tenaga kependidikan

4. Penurunan pangkat dan jabatan akademik/fungsional

5. Pencabutan hak untuk diusulkan sebagai guru besar profesor/ahli peneliti utama bagi yang memenuhi syarat.

6. Pemberhentian dengan hormat dari status sebagai dosen/peneliti/tenaga kependidikan

7. Pemberhentian dengan tidak hormat dari status sebagai dosen/peneliti/tenaga kependidikan; atau

8. Pembatalan ijazah yang diperoleh dari perguruan tinggi yang bersangkutan.

Sedangkan jika yang bersangkutan menyandang sebutan guru besar/profesi/ahli peneliti utama, maka yang bersangkutan diberikan sanksi tambahan berupa pemberhentian jabatan dari guru besar/profesi/ahli peneliti utama oleh Menteri atau pejabat yang berwenang atas usul perguruan tinggi yang diselenggarakan oleh pemerintah atau atas usul perguruan tinggi yang diselenggarakan oleh masyarakat melalui Koordinator Perguruan Tinggi Swasta (Pasal 12 ayat 5 Permendiknas No. 17 Tahun 2010). Dalam Pasal 13 disebutkan bahwa penjatuhan sanksi administratif sebagaimana diatur dalam Pasal 12 dilakukan secara proporsional berdasarkan sikap batin pelaku (sengaja atau lalai) serta tidak menghapuskan sanksi yang ada pada peraturan perundangundangan lainnya.

Berdasarkan analisis atas UUHC dapat dikatakan bahwa plagiarisme yang dilakukan oleh seseorang berdasarkan ketentuan UUHC merupakan tindak pidana yang melanggar hak moral dan hak ekonomi dari pencipta, sedangkan pelanggaran atas hak ekonomi dari pencipta biasanya disebut dengan pembajakan hak cipta, selain itu kedua tindakan tersebut bisa dilakukan oleh siapa saja (berlaku umum). Sedangkan jika didasarkan pada tujuan yang ingin dicapai oleh pelaku plagiarisme diajukan untuk mendapatkan pengakuan (integritas) sebagai pencipta dengan cara mencederai integritas pemilik hak cipta, sedangkan pembajakan hak cipta lebih ditujukan untuk mendapatkan keuntungan ekonomi dengan cara melanggar hak ekonomi pencipta. 
Permendiknas No. 17 Tahun 2010 tersebut dapat disimpulkan bahwa peraturan telah memberikan perlindungan hukum yang memadai dengan adanya perumusan sanksi administratif yang jelas. Permendiknas No. 17 Tahun 2010 ini memandang bahwa plagiarisme sebagai tindakan yang tercela secara etis dan moral akan tetapi tidak menganggap sebagai tindak pidana. Hal ini dapat dicermati dari rumusan sanksi berupa sanksi administratif dan bukan sanksi pidana. Hal ini bertentangan dengan ketentuan Pasal 25 UU Sisdiknas yang menyatakan plagiarisme adalah tindak pidana karena adanya sanksi pidana berupa penjatuhan pidana penjara dalam kurun waktu tertentu dan penjatuhan pidana denda. Dengan demikian dapat disimpulkan bahwa baik UU Sisdiknas maupun Permendiknas No. 17 Tahun 2010 memiliki sudut pandang yang berbeda dalam memberikan perlindungan hukum bagi pencipta yang dirugikan karena tindakan plagiarisme, seharusnya antara UU Sisdiknas dan Permendiknas No. 17 Tahun 2010 sejalan dan saling melengkapi.

\section{KESIMPULAN}

Dari uraian di atas dapat ditarik kesimpulan bahwa perlindungan hukum pada UUHC, UU Sisdiknas dan Permendiknas No. 17 Tahun 2010 didasarkan pada 5 parameter yaitu pengakuan hak bagi pencipta, penetapan plagiarisme sebagai tindak pidana, perumusan sanksi pidana, adanya pidana tambahan, dan mekanisme penyelesaian sengketa. Parameter tersebut telah memberikan perlindungan hukum bagi pencipta yang paling memadai sehingga pelaku dapat dipertanggungjawabkan secara Pidana , Administrasi maupun Perdata dapat juga diterapkan kepada Institusi.

\section{Daftar Pustaka}

\section{Buku}

M. Djumhana dan R. Djubaedillah, Hak Milik Intelektual (Sejarah, Teori dan Prakteknya di Indonesia), Bandung: Citra Aditya Bakti, 1997.

\section{Jurnal}

Fitriah, Nikmah, "Tinjauan Yuridis tentang Kriteria Pencemaran dan Perusakan Lingkungan Menurut UU No. 32 Tahun 2009 Tentang Pengelolaan Lingkungan Hidup", Halu Oleo Law Review (HOLREV), Vol. 1, Issue 2, September 2017, 
http://ojs.uho.ac.id/index.php/holrev/article/view/3643/3137, diakses pada tanggal 17 Februari 2018.

\section{Peraturan perundang-undangan}

Kitab Undang-Undang Hukum Pidana (KUHP)

Undang-Undang RI Nomor 28 tahun 2014 tentang Hak Cipta

Undang-Undang RI Nomor 20 tahun 2003 tentang Sistem Pendidikan Nasional

Undang-Undang RI Nomor 11 tahun 2008 tentang Informasi Teknologi dan Transaksi Elektronik

PP Mendiknas No. 17 tahun 2010 tentang Pencegahan dan Penanggulangan Plagiat di Perguruan Tinggi

\section{Internet}

“Gelar Magister Zuliansyah Tak Dicabut", Detikcom, https://news.detik.com/berita/d1344458/gelar-magister-zuliansyah-tak-dicabut, 23 April 2010. diakses pada tanggal 11 Januari 2018.

"Marak, Plagiarisme Internet di Sekolah", Detikcom, http://inet.detik.com/cyberlife/d1382658/marak-plagiarisme-internet-di-sekolah-, 21 Jun 2010, diakses pada tanggal 9 Januari 2018.

Chandra, Wahyu, "Motif Dibalik Tuduhan Plagiarisme Penyair Taufik Ismail", Kompasiana, https://www.kompasiana.com/wahyuch/motif-di-balik-tuduhan-plagiarismepenyair-taufik-ismail 5500a6baa333119f6f511b49, 3 April 2011, diakses pada tanggal 11 Januari 2018.

Jurnal Skirpsi Thesis, http://www.Jurnalskripsithesis.com, diakses pada tanggal 10 Januari 2018. 